\title{
Can socioeconomic factors explain the local
salient plants in a social-ecological system?
}

\section{Rosemary da Silva Sousa ${ }^{1}$, Patrícia Muniz de Medeiros $^{2}$ (D) and Ulysses Paulino Albuquerque* (D)}

Received: September 25, 2018

Accepted: February 28, 2019

\begin{abstract}
The aim of this work was to determine whether socioeconomic factors explain the importance of culturally salient plants to social-ecological systems. Extractive communities of the Araripe-Apodi Environmental Protection Area in Northeast Brazil were studied, and a random sample of the population was selected. Quantitative variables (education, age and income) were analyzed using Spearman correlations, while categorical variables (gender and occupation) were analyzed using Mann-Whitney tests. Relationships between socioeconomic factors and the importance of culturally salient plants were all weak. Nevertheless, age influenced the local importance of the largest number of species. Other factors not considered in this study (historical, cultural, ecological, and psychological) may be outstanding predictors of the importance of culturally salient plants and should be studied in future investigations.
\end{abstract}

Keywords: culturally salient plants, ethnobiology, ethnobotany, plant extraction, socioeconomic factors

\section{Introduction}

Social-ecological systems have for a while been described by simple models resulting in solutions that are not feasible for evaluating resource overexploitation (Ostrom 2007). Social-ecological systems are complex and composed of multiple subsystems, different elements included in these subsystems, at multiple levels (Pennisi 2003; Ostrom 2009). For example, for Ostrom (2009), each subsystem is composed of different variables that affect the organization and function of these systems. In this article, we evaluated the role of culturally salient species in social-ecological systems structured around extractivism of non-timber forest products, as well as the effect of socioeconomic variables on people's relashionships with these species.

The influence of socioeconomic factors on the knowledge and use of plant species has been the focus of several ethnobotanical studies. These studies assessed this association in different ways, including from useful plants in general (see Reyes-García et al. 2005; 2007; Souto \& Ticktin 2012; Beltrán-Rodríguez et al. 2014) to certain types of uses, such as food plants (see Ladio \& Lozada 2004), medicinal (see Voeks 2007; Vandebroek \& Balick 2012) and timber (see Ramos et al. 2008; Medeiros et al. 2012).

The findings of these studies varied depending on the approach taken by each investigator. Specifically, for medicinal plants, Case et al. (2005) affirmed that older people had more knowledge than younger people. However, Hanazaki et al. (2000) did not find this association when they considered the totality of the useful species. As for education and income, studies on useful plants (in general) suggested that knowledge decreased with the increase of education (see Benz et al. 2000; Saynes-Vásquez et al. 2013) and income (see Varughese \& Ostrom 2001; Holmes 2003). Regarding gender, research on medicinal plants indicated

1 Laboratório de Ecologia e Evolução de Sistemas Socioecológicos, Departamento de Botânica, Centro de Biociências, Universidade Federal de Pernambuco, 50670-901, Recife, PE, Brazil

2 Laboratório de Ecologia, Conservação e Evolução Biocultural, Centro de Ciências Agrárias, Universidade Federal de Alagoas, 57100-000 , Rio Largo, AL, Brazil

* Corresponding author: upa677@hotmail.com 
that women knew more than men (see Caniago \& Siebert 1998; Voeks \& Leony 2004); nonetheless, when the entire local knowledge system was considered, it was found that men knew more than women (see Hanazaki et al. 2000; Kristensen \& Balslev 2003; Saynes-Vásquez et al. 2013). Analyses that included useful plants also demonstrated the influence of the type of occupation on local knowledge and argued that the most dependent activities of the natural environment were the most associated with the maintenance of local ecological knowledge (see Martínez-Ballesté et al. 2006; Saynes-Vásquez et al. 2013).

To the best of our knowledge, most of the research conducted so far focused on the relation between socioeconomic factors and the number and diversity of plants that were known or used by people for various purposes. Therefore, there is a lack of studies that relate these factors to the importance that people attach to species. In addition, all sutudies focused on the totality of the species considered useful or on use categories, for example, medicinal plants. However, authors stated that in certain social-ecological systems, there were species that played a unique role in the culture, and they were essential for people's relationship with and adaptation to the environment (Cristancho \& Vining 2004), for cultural identity (Garibaldi \& Turner 2004) and for the maintenance of the system (Platten \& Henfrey 2009). In this study, we focused on the effects of socioeconomic variables on culturally salient species, a group of prominent species of the social-ecological system. Hence, an analysis that checks the influence of socioeconomic variables on a different set of species would be able to show how certain elements of a social-ecological system can behave.

As a scenario of study, we use two extractive communities of the Brazilian northeast that depend on plant resources to meet their most basic needs and that have a long history of forest resource use (IBAMA 2004). Our main question is: do socioeconomic factors influence the importance of culturally salient species? Our hypothesis is that culturally salient species have their local importance influenced by socioeconomic factors.

\section{Materials and methods}

\author{
Study area
}

Two of the 20 human communities that are located around the Araripe-Apodi National Forest, in Araripe-Apodi Environmental Protection Area (EPA), northeastern Brazil, were selected: Horizonte and Macaúba. These communities were selected because one of their main activities, besides subsistence agriculture, is the extraction of forest resources in the Araripe National Forest (FLONA Araripe) (IBAMA
2004). Other criteria for choosing these communities were their proximity to the EPA (IBAMA 2004) and the availability of ethnobotanical and socioeconomic data.

Both Horizonte and Macaúba have a long and intensive history of plant species extraction. In Horizonte the extraction of "pequi" (Caryocar coriaceum Wittm.) (Cavalcanti et al. (2015a) and "faveira" (Dimorphandra gardneriana Tul) are the most conspicuous. The fruits of $C$. coriaceum are mainly marketed for food and medicinal purposes. The fruits of $D$. gardneriana are sold to pharmaceutical industries due to the high content of the flavonoids rutin and quercetin (see Silva et al. 2017). The extractivism of these two species generates different productive chains distinct models of commercial appropriation: C. coriaceum is related to local traditions and D. gardneriana meets industrial demands (Silva et al. 2017). The community of Macaúba, besides using these two species, notoriously extracts the palm "babaçu" (Atallea speciosa Mart. ex Spreng), whose resources have high commercial importance for community members, especially for women (Campos et al. 2015b).

Horizonte had 1,120 people and Macaúba, 1,110 (unpublished data from the Population Census of the Family Health Strategy ${ }^{1}$ ). Each of these communities has a nursery and a primary school, and the other levels of education are only offered in the surrounding towns. These communities also have a health center, where medical care is given on a weekly basis.

This research was approved by the System of Authorization and Information on Biodiversity (authorization no. 27093-1) because it was conducted in the Protected Area. The project was also approved by the Research Ethics Committee of the University of Pernambuco (authorization No. 139.813 and Certificate of Presentation to Ethics Assessment no. 02187512.8.0000.5207). In addition, the community members selected for the study were asked to participate and sign the Free and Informed Consent Term after being given the purpose and methods of the project. This allowed for the collection and publication of information, as established by current legislation (Resolution 466/12 of the National Health Council).

\section{Selection of informants}

We selected informants of 18 years of age and over in the communities of Horizonte and Macaúba. We conducted a gender and age group stratification with 10 -year intervals (18-28, 29-38, 39-48, 49-58, 59-68, 69 on wards). From the sample of the total number of people, the proportional sample size of each stratum was defined by means of a probabilistic sampling (see Albuquerque et al. 2014a for calculations). A random sample (without replacement) with the names of people to be interviewed was performed in BioEstat 5.0 (Ayres et al. 2007).

\footnotetext{
${ }^{1}$ According to the National Primary Care Policy of the Ministry of Health, the Family Health Strategy (ESF), formerly the Family Health Program (PFS), "aims at
} reorganizing primary care in the country [as well as] increase the resolution and impact on the health situation of individuals and collectivities" (Brasil 2012). 
It was noteworthy that in the recognition of the area, health agents of the communities reported that some people had migrated for temporary work to other states. Thus, the sample was composed only by people who were living in the communities at the time of the data collection. In Macaúba, from the total of 249 people to be interviewed, only 193 were found. The other informants (56) were traveling (38), working in neighboring municipalities and were not at home on weekends (seven), sick (mental problems, deaf and dumb) (six), deceased (three) and refused to participate (two). However, the representativeness of the study was guaranteed by the sample size, which was higher than the acceptable value of 330 people, considering a margin of error of $5 \%$ and a confidence interval of $95 \%$ (177 people in Horizonte and 193 in Macaúba, a total of 370 people).

The monthly income among those interviewed ranged from zero to 2262,00 USD (1 USD = 3,90 BRL, April 2013). This discrepancy also occurred in education because there were people from illiterate to post-graduates. Approximately $50 \%$ of people interviewed were concerned with family farming, others worked in the educational sector, trade, health and other activities. Others were unemployed ( $4 \%$ in Horizonte and $9 \%$ in Macaúba), students ( $5 \%$ ) or housewives (approximately $15 \%$ ). The variation in the monthly income, education and occupation occurred for both men and women. It was also noteworthy that many of the communities (approximately $50 \%$ ) received benefits from the federal government, such as retirement, pension, family support and crop insurance.

\section{Data collection}

Between September 2011 and August 2013, semistructured interviews were conducted (see Albuquerque et al. 2014b) to collect socioeconomic data, such as age, gender, education, occupation and monthly income. The free listing technique was also used (see Albuquerque et al. 2014b) to access culturally salient species. Such plants were cited when the following question was asked: "Suppose that for some reason you will live in a place far from here, what are the ten plants you would surely take?" This question was asked in an attempt to separate a set of culturally salient species from the other species of the social-ecological system. As informants cited the plants, it was also asked why they chose each plant, and finally, it was requested for them to order the plants according to their importance. Ten plants were chosen so that ordering was not tiresome and exhausting for the informants.

The botanical material was collected through the guidedtour technique (see Albuquerque et al. 2014b). The species were herborized using standard techniques of preparation, drying and mounting of exsiccates (see Santos et al. 2014). The identification of the samples was conducted by experts and comparisons with exsiccates deposited in herbaria. After identification, the species were included in the collection of the Herbarium Professor Vasconcelos Sobrinho of Universidade Federal Rural de Pernambuco.

\section{Data analysis}

The Cultural Salience in Anthropac 4.0 (Borgatti 1996), was calculated using the list of plants obtained through the free listing technique which considered the number of times and the order in which the plants were mentioned. The ten plants with the highest cultural salience were selected. Informants cited plants that were not among the ten most salient, these plants were not analysed; therefore, the species on the original list of each respondent were separated by those species that were among the ten most salient and their respective positions in the ranking given by the interviewee. Thus, for each informant, there was a list with only the salient species and the ordering of each one given by the respondent in the original list. Then, the local importance value of each plant for each informant was calculated by assigning a value/score from 1.00 to 0.1 for each of them, based on the order of the original list of each respondent.

For example, for an informant who cited the ten most salient plants, if he put species B first, its importance value was 1:00; if species $A$ was second, its value was 0.9 , and so on, until reaching species $\mathrm{F}$, which came in tenth place with a value of 0.1 . In the case of an informant who cited only three species out of the ten most salient, if he put species $A$ in the first place, the importance value of it was 1:00; if species $C$ was second, its value was 0.9 ; and if species $B$ was third, its value was 0.8 .

In order to verify if the socioeconomic factors influence the value of local importance each species, the Spearman Correlation was used for quantitative variables (age, education and monthly individual income) and Mann-Whitney tests for categorical variables (gender and occupation), using the software R Studio (R Development Core Team 2013). For the education variable, the data were classified in ascending order considering the lowest level of education (not literate: 1 , incomplete elementary school: 2 , complete elementary school: 3 , incomplete secondary school: 4 , incomplete higher education degree 6 , complete higher education degree: 7 ).

\section{Results}

Table 1 shows the ten culturally salient species in each community studied. Seven species were shared by the two communities, three species were only mentioned in Horizonte and three in Macaúba. This table also has the value of cultural salience and the variation range of the value of the local importance of each species in each community, as well as the arithmetic mean and standard deviation of this value. The most culturally salient species in both communities were $C$. coriaceum. Only in Horizonte were D. gardneriana and in Macaúba were Attalea speciosa, all of which are tree species. 
Table 1. Culturally salient species for communities of Horizonte (H) and Macaúba (M), Araripe-Apodi Environmental Protection Area, Ceará, northeast Brazil, with their respective scientific and common names, value of Cultural Salience, variation of the value of the local importance and a mean and standard deviation of this value, the number $\left(\mathrm{N}^{\circ}\right)$ of people that cited each species and the register number $\left(\mathrm{N}^{\circ}\right)$ at Vasconcelos Sobrinho Herbarium of the Federal Rural University of Pernambuco (PEUFR). (-): No data, since the species was not cited in the referred community.

\begin{tabular}{|c|c|c|c|c|c|c|c|c|c|c|}
\hline \multirow[t]{2}{*}{$\begin{array}{c}\text { Familyl } \\
\text { Scientific Name }\end{array}$} & \multirow[t]{2}{*}{$\begin{array}{l}\text { Popular } \\
\text { Name }\end{array}$} & \multicolumn{2}{|c|}{$\begin{array}{l}\text { Cultural } \\
\text { Salience }\end{array}$} & \multicolumn{2}{|c|}{$\begin{array}{l}\text { Variation of the value } \\
\text { of local importance }\end{array}$} & \multicolumn{2}{|c|}{$\begin{array}{l}\text { Mean and standard } \\
\text { deviation of the local } \\
\text { importance value }\end{array}$} & \multicolumn{2}{|c|}{$\begin{array}{l}N^{0} \text { of } \\
\text { people }\end{array}$} & \multirow[t]{2}{*}{$\begin{array}{l}\mathrm{N}^{0} \text { of Register } \\
\text { at PEUFR }\end{array}$} \\
\hline & & H & M & H & M & H & M & H & M & \\
\hline \multicolumn{11}{|l|}{ Anacardiaceae } \\
\hline Anacardium occidentale L. & cajuí & 0.13 & 0.06 & 0.1 to 0.9 & 0.1 to 1.00 & $0.50 \pm 0.27$ & $0.58 \pm 0.29$ & 44 & 21 & SOUSA,R.(51651) \\
\hline \multicolumn{11}{|l|}{ Annonaceae } \\
\hline Annona coriacea Mart. & araticum & 0.14 & - & 0.1 to 1.00 & - & $0.55 \pm 0.30$ & - & 51 & - & SOUSA,R.(51558) \\
\hline \multicolumn{11}{|l|}{ Apocynaceae } \\
\hline Himatanthus drasticus (Mart.) Plumel & janaguba & 0.30 & 0.13 & 0.1 to 1.00 & 0.2 to 1.00 & $0.55 \pm 0.30$ & $0.62 \pm 0.28$ & 84 & 42 & SOUSA,R.(51605) \\
\hline Hancornia speciosa Gomes & mangaba & 0.36 & 0.12 & 0.1 to 1.00 & 0.4 to 0.9 & $0.55 \pm 0.30$ & $0.65 \pm 0.19$ & 96 & 41 & CAMPOS,L.(51741) \\
\hline \multicolumn{11}{|l|}{ Arecaceae } \\
\hline Attalea speciosa Mart ex. Spreng. & babaçu & - & 0.47 & - & 0.5 to 1.00 & - & $0.75 \pm 0.19$ & - & 134 & Identified in place \\
\hline Acrocomia intumescens Drude & macaúba & - & 0.12 & - & 0.2 to 1.00 & - & $0.62 \pm 0.28$ & - & 43 & Identified in place \\
\hline \multicolumn{11}{|l|}{ Caryocaraceae } \\
\hline Caryocar coriaceum Wittm. & pequi & 0.98 & 0.84 & 0.4 to 1.00 & 0.4 to 1.00 & $0.68 \pm 0.23$ & $0.70 \pm 0.22$ & 163 & 181 & SOUSA, R.S (51606) \\
\hline \multicolumn{11}{|l|}{ Fabaceae-Caesalpinioideae } \\
\hline Dimorphandra gardneriana Tul. & faveira & 0.52 & - & 0.1 to 1.00 & - & $0.55 \pm 0.30$ & - & 129 & - & Identified in place \\
\hline \multicolumn{11}{|l|}{ Fabaceae-Mimosoideae } \\
\hline Stryphnodendron rotundifolium Mart. & barbatenã & 0.28 & 0.06 & 0.1 to 1.00 & 0.3 to 1.00 & $0.55 \pm 0.30$ & $0.65 \pm 0.24$ & 83 & 22 & SOUSA, R.S (51575) \\
\hline Parkia platycephala Benth. & visgueiro & 0.15 & 0.05 & 0.1 to 0.9 & 0.2 to 1.00 & $0.50 \pm 0.27$ & $0.60 \pm 0.27$ & 56 & 25 & SOUSA, R.S (51569) \\
\hline \multicolumn{11}{|l|}{ Malpighiaceae } \\
\hline Byrsonima sericea DC & murici & 0.21 & 0.07 & 0.1 to 0.9 & 0.3 to 0.9 & $0.50 \pm 0.27$ & $0.60 \pm 0.22$ & 83 & 34 & SOUSA, R.S (51564) \\
\hline \multicolumn{11}{|l|}{ Myrtaceae } \\
\hline Eugenia sp & goiabinha & 0.12 & - & 0.2 to 1.00 & - & $0.60 \pm 0.27$ & - & 43 & - & Identified in place \\
\hline Psidium myrsinites DC & araçá & - & 0.06 & - & 0.1 to 0.9 & - & $0.57 \pm 0.26$ & - & 23 & BALCAZAR, A (6700) \\
\hline
\end{tabular}

Do socioeconomic factors influence the importance of culturally salient species?

It has been found that the influence of socioeconomic factors on the value of the local importance of culturally salient species is weak, although some relationships were significant (Tabs. 2-7). In Horizonte, four species (Anacardium occidentale, Byrsonima sericea, C. coriaceum and Eugenia sp.) were not influenced by the factors, other five species (Annona coriaceae, D. gardneriana, Himatanthus drasticus, Parkia platychepala, Stryphnodendron rotundifolium) had the value of local importance influenced by one or two factors, and only Hancornia speciosa had the value of local importance influenced by all factors analyzed.

In this community, age influenced the value of local importance of four species. The smaller the age, the greater the local importance value of $A$. coriaceae, $H$. speciosa and $H$. drasticus, while the inverse relation was observed for D. gardneriana. The occupation factor influenced the value of local importance of three species. Farmers gave greater value of local importance to $H$. speciosa and $H$. drasticus, while those that are not farmers gave greater value to $P$. platychepala. Education influenced the local importance of two species. The higher the schooling level the lower the value of local importance given to $A$. coriaceae and $H$. speciosa. The gender also influenced the local importance value of two species. Men gave greater local importance values to $D$. gardneriana and $H$. speciosa. The income only influenced the value of local importance of $H$. speciosa, the lower the income the greater the value of importance given to this species.

It was worthy to note that the most culturally salient species in this community, $C$. coriaceum (cultural salience $=0.98$ ), whose local importance values were high (0.4 to 1.00) does not have its local importance values influenced by any of the socioeconomic factors analyzed here.

In Macaúba, three species (A. speciosa, B. sericea and C. coriaceum) were not influenced by the factors studied, while other five species (A. intumescens, A. occidentale, $P$. platychepala, Psidium myrsinites and $S$. rotundifolium) had the value of local importance influenced by one or two factors. Another two species were influenced by almost all factors analyzed: $H$. speciosa and $H$. drasticus.

In this community, age influenced the value of local importance of five species. The lower the age, the greater the local importance value of $A$. occidentale, $H$. speciosa, $H$. drasticus, P. platychepala and P. myrsinites. The income influenced the value of local importance of four species. The lower the income, the greater the local importance value of $H$. drasticus, P. platychepala and P. myrsinites, while 
Table 2. Spearman correlation coefficients (rs) for the ratio between socioeconomic factors (quantitative variables) and values of local importance of the species in the Horizonte community, Araripe Apodi Environmental Protection Area,

Northeast Brazil.

\begin{tabular}{|c|c|c|}
\hline Species & Variable & Spearman (rs) \\
\hline \multirow{3}{*}{ Anacardium occidentale } & Education & 0.00 \\
\hline & Age & -0.10 \\
\hline & Income & 0.07 \\
\hline \multirow{3}{*}{ Annona coriacea } & Education & $-0.25^{* * *}$ \\
\hline & Age & $0.23^{* *}$ \\
\hline & Income & 0.00 \\
\hline \multirow{3}{*}{ Byrsonima sericea } & Education & -0.08 \\
\hline & Age & 0.08 \\
\hline & Income & 0.07 \\
\hline \multirow{3}{*}{ Caryocar coriaceum } & Education & 0.05 \\
\hline & Age & -0.05 \\
\hline & Income & -0.06 \\
\hline \multirow{3}{*}{ Dimorphandra gardneriana } & Education & 0.09 \\
\hline & Age & $-0.23^{* *}$ \\
\hline & Income & -0.13 \\
\hline \multirow{3}{*}{ Eugenia sp. } & Education & -0.09 \\
\hline & Age & -0.02 \\
\hline & Income & -0.06 \\
\hline \multirow{3}{*}{ Hancornia speciosa } & Education & $-0.34^{* * *}$ \\
\hline & Age & $0.40^{* * *}$ \\
\hline & Income & $0.21^{* *}$ \\
\hline \multirow{3}{*}{ Himatanthus drasticus } & Education & -0.02 \\
\hline & Age & $0.17^{*}$ \\
\hline & Income & 0.07 \\
\hline \multirow{3}{*}{ Parkia platycephala } & Education & 0.05 \\
\hline & Age & -0.04 \\
\hline & Income & 0.13 \\
\hline \multirow{3}{*}{ Stryphnodendron rotundifolium } & Education & -0.05 \\
\hline & Age & 0.02 \\
\hline & Income & -0.11 \\
\hline
\end{tabular}

Table 3. Means and results of the comparison of values of local importance of species by gender (categorical variable) performed through the Mann-Whitney test for the Horizonte community, Araripe Apodi Environmental Protection Area, Northeast Brazil.

\begin{tabular}{|c|c|c|c|}
\hline Species & $\begin{array}{c}\text { Mean } \\
\text { women }\end{array}$ & $\begin{array}{c}\text { Mean } \\
\text { men }\end{array}$ & $\begin{array}{c}\text { Mann- } \\
\text { Whitney (W) }\end{array}$ \\
\hline Anacardium occidentale & 0.12 & 0.17 & 3598.5 \\
\hline Annona coriacea & 0.18 & 0.14 & 4079.5 \\
\hline Byrsonima sericea & 0.23 & 0.27 & 3625.5 \\
\hline Caryocar coriaceum & 0.89 & 0.91 & 3745 \\
\hline Dimorphandra gardneriana & 0.45 & 0.63 & $2809.5^{* * *}$ \\
\hline Eugenia sp. & 0.13 & 0.12 & 4003 \\
\hline Hancornia speciosa & 0.26 & 0.48 & $2738^{* * *}$ \\
\hline Himatanthus drasticus & 0.32 & 0.30 & 4095.5 \\
\hline Parkia platycephala & 0.17 & 0.16 & 3918 \\
\hline Stryphnodendron rotundifolium & 0.31 & 0.28 & 4055 \\
\hline
\end{tabular}

${ }^{*} \mathrm{p}<0.05 ;{ }^{* *} \mathrm{p}<0.01 ;{ }^{* * *} \mathrm{p}<0.001$
Table 4. Means and results of the comparison of values of local importance of species by occupation (categorical variable) performed through the Mann-Whitney test for the Horizonte community, Araripe Apodi Environmental Protection Area, Northeast Brazil.

\begin{tabular}{|c|c|c|c|}
\hline Species & $\begin{array}{c}\text { Mean } \\
\text { Farmer }\end{array}$ & $\begin{array}{c}\text { Mean non- } \\
\text {-farmer }\end{array}$ & $\begin{array}{c}\text { Mann- } \\
\text { Whitney (W) }\end{array}$ \\
\hline Anacardium occidentale & 0.12 & 0.17 & 3849 \\
\hline Annona coriacea & 0.16 & 0.15 & 4141 \\
\hline Byrsonima sericea & 0.25 & 0.25 & 4105 \\
\hline Caryocar coriaceum & 0.91 & 0.89 & 4188 \\
\hline Dimorphandra gardneriana & 0.53 & 0.53 & 3943 \\
\hline Eugenia sp & 0.13 & 0.12 & 4251 \\
\hline Hancornia speciosa & 0.47 & 0.26 & $5257^{* * *}$ \\
\hline Himatanthus drasticus & 0.36 & 0.26 & 4527.5 \\
\hline Parkia platycephala & 0.11 & 0.21 & $3397^{*}$ \\
\hline Stryphnodendron rotundifolium & 0.36 & 0.22 & $4820^{* *}$ \\
\hline${ }^{*} \mathrm{p}<0.05 ;{ }^{* *} \mathrm{p}<0.01 ;{ }^{* * *} \mathrm{p}<0.001$ & & & \\
\hline
\end{tabular}

Table 5. Spearman correlation coefficients (rs) for the ratio between socioeconomic factors (quantitative variables) and values of local importance of the species in the Macaúba community, Araripe Apodi Environmental Protection Area, Northeast Brazil.

\begin{tabular}{|c|c|c|}
\hline Species & Variable & Spearman (rs) \\
\hline \multirow{3}{*}{ Acrocomia intumescens } & Education & 0.11 \\
\hline & Age & -0.12 \\
\hline & Income & $-0.19^{* *}$ \\
\hline \multirow{3}{*}{ Anacardium occidentale } & Education & -0.04 \\
\hline & Age & $0.16^{*}$ \\
\hline & Income & 0.04 \\
\hline \multirow{3}{*}{ Attalea speciosa } & Education & -0.01 \\
\hline & Age & -0.01 \\
\hline & Income & 0.02 \\
\hline \multirow{3}{*}{ Byrsonima sericea } & Education & -0.05 \\
\hline & Age & 0.14 \\
\hline & Income & 0.13 \\
\hline \multirow{3}{*}{ Caryocar coriaceum } & Education & -0.03 \\
\hline & Age & 0.12 \\
\hline & Income & -0.09 \\
\hline \multirow{3}{*}{ Hancornia speciosa } & Education & $-0.18^{*}$ \\
\hline & Age & $0.34^{* * *}$ \\
\hline & Income & 0.10 \\
\hline \multirow{3}{*}{ Himatanthus drasticus } & Education & -0.07 \\
\hline & Age & $0.20^{* *}$ \\
\hline & Income & $0.19^{* *}$ \\
\hline \multirow{3}{*}{ Parkia platycephala } & Education & -0.02 \\
\hline & Age & $0.22^{* *}$ \\
\hline & Income & $0.21^{* *}$ \\
\hline \multirow{3}{*}{ Psidium myrsinites } & Education & $-0,09$ \\
\hline & Age & $0.17^{*}$ \\
\hline & Income & $0.14^{*}$ \\
\hline \multirow{3}{*}{ Stryphnodendron rotundifolium } & Education & $0.15^{*}$ \\
\hline & Age & 0.11 \\
\hline & Income & -0.01 \\
\hline
\end{tabular}


Table 6. Means and results of the comparison of values of local importance of the species by gender (categorical variable) performed through the Mann-Whitney test for the Macaúba community, Araripe Apodi Environmental Protection Area, Northeast Brazil.

\begin{tabular}{|c|c|c|c|}
\hline Species & $\begin{array}{c}\text { Mean } \\
\text { women }\end{array}$ & $\begin{array}{c}\text { Mean } \\
\text { men }\end{array}$ & Mann-Whitney (W) \\
\hline Acrocomia intumescens & 0.2 & 0.14 & 4950.5 \\
\hline Anacardium occidentale & 0.06 & 0.09 & 4344 \\
\hline Attalea speciosa & 0.63 & 0.59 & 4251 \\
\hline Byrsonima sericea & 0.09 & 0.14 & 4159.5 \\
\hline Caryocar coriaceum & 0.88 & 0.94 & 4273.5 \\
\hline Hancornia speciosa & 0.11 & 0.22 & $3962^{*}$ \\
\hline Himatanthus drasticus & 0.11 & 0.23 & $3860^{* *}$ \\
\hline Parkia platycephala & 0.07 & 0.08 & 4449 \\
\hline Psidium myrsinites & 0.05 & 0.12 & 4163 \\
\hline Stryphnodendron rotundifolium & 0.09 & 0.08 & 4594 \\
\hline
\end{tabular}

${ }^{*} \mathrm{p}<0.05 ;{ }^{* *} \mathrm{p}<0.01 ;{ }^{* * *} \mathrm{p}<0.001$

the opposite relation was observed for $A$. intumescens. The occupation influenced the value of local importance of three species. Farmers gave greater value of local importance to $H$. speciosa, $H$. drasticus and S. rotundifolium. Education influenced the value of local importance of two species. The lower the schooling level the higher the local importance value of $S$. rotundifolium, the inverse relation was observed for $H$. speciosa. The gender factor also influenced the value of local importance of two species. Men gave greater value of local importance to $H$. speciosa and $H$. drasticus.

Interestingly, $A$. speciosa and $C$. coriaceum, the species that achieved greater cultural salience $(0.84$ e 0.47$)$ in this community did not present their local importance values influenced by the socioeconomic factors.

\section{Discussion}

The influence of socioeconomic factors on the value of local importance of culturally salient species is not as strong as it has been recorded for the influence of these factors on the knowledge and use of useful plants in general in the two studied communities, it was observed that most of the species (nine in Horizonte and eight in Macaúba) either did not have the local importance value influenced by the factors or were influenced by a maximum of two. This indicates that culturally salient species may have other predictors that best explain their local importance, in addition to socioeconomic ones.

Historical, cultural, ecological, psychological factors may be predictors of socioeconomic factors to explain the importance of culturally salient plants. In our scenario, some of these coadjuvant predictors were studied. Silva et al. (2019) claim that the comparison of historical and current aerial images of the landscape indicates that the
Table 7. Means and results of the comparison of values of local importance of species by occupation (categorical variable) performed through the Mann-Whitney test for the Macaúba community, Araripe Apodi Environmental Protection Area, Northeast Brazil.

\begin{tabular}{|c|c|c|c|}
\hline Species & $\begin{array}{c}\text { Mean } \\
\text { Farmer }\end{array}$ & $\begin{array}{c}\text { Mean non- } \\
\text {-farmer }\end{array}$ & $\begin{array}{c}\text { Mann- } \\
\text { Whitney (W) }\end{array}$ \\
\hline Acrocomia intumescens & 0.14 & 0.2 & 4315 \\
\hline Anacardium occidentale & 0.08 & 0.07 & 4823.5 \\
\hline Attalea speciosa & 0.65 & 0.58 & 4970.5 \\
\hline Byrsonima sericea & 0.14 & 0.09 & 5017.5 \\
\hline Caryocar coriaceum & 0.95 & 0.88 & 5080.5 \\
\hline Hancornia speciosa & 0.21 & 0.12 & $5165^{*}$ \\
\hline Himatanthus drasticus & 0.21 & 0.12 & $5173^{*}$ \\
\hline Parkia platycephala & 0.06 & 0.08 & 4637 \\
\hline Psidium myrsinites & 0.09 & 0.08 & 4749.5 \\
\hline Stryphnodendron rotundifolium & 0.14 & 0.04 & $5276.5^{* *}$ \\
\hline
\end{tabular}

${ }^{*} \mathrm{p}<0.05 ;{ }^{* *} \mathrm{p}<0.01 ;{ }^{* * *} \mathrm{p}<0.001$

density of plants increased in managed forested areas where agricultural practices were interrupted; this study also shows that phytosociological data for the managed areas present a greater abundance of the more salient useful species compared to useful species that present less local importance. Cavalcanti et al. (2015a) described the extraction of oil from the fruit of C. coriaceum as an important traditional activity in the local economy and culture.

Despite the weak influence of the socioeconomic factors analyzed, age was the factor that affected the value of local importance of a greater number of species (four in Horizonte and five in Macaúba). The younger people in the communities gave more importance to certain species. The possibility of generating income through the collection of resources may be the explanation for the younger members to give greater importance to some species, since the species most cited by the young people have commercial potential. D. gardneriana, for example, is a species whose fruits are commercialized in Horizonte for pharmaceutical companies, forming a local productive chain (see Silva et al. 2017). H. drasticus, besides having latex used for medicinal purposes in both communities, is also marketed in the region (see Baldauf \& Santos 2013). In addition to the commercial potential, the younger people of the communities value the species by the organoleptic properties (flavor and smell) of their fruits, such as $A$. occidentale, $A$. coriaceae, $H$. speciosa and $P$. myrsinites, whose collection occurs together with other resources of local preference: B. sericea wood (see Cavalcanti et al. 2015b), fruits of C. coriaceum (see Campos et al. 2015a) and A. speciosa (Campos et al. 2015b). This indicates that even if the search for work and industrial goods in urban areas reduced local knowledge (Hanazaki et al. 2000), it was observed that young people still recognized the importance of the trade of some plant resources for the acquisition of goods and services. 
The occupation influenced the value of local importance of three species both in Horizonte and in Macaúba. The farmers gave more local importance values to the species, except in the case of $P$. platychepala. Farmers were responsible for most of the local importance of $H$. speciosa e $H$. drasticus in both communities and S. rotundifolium in Macaúba. In the case of $S$. rotundifolium, such local importance was motivated by the medicinal use and the commercial potential (Feitosa et al. 2014). Therefore, we suggested three reasons why farmers gave it more importance: (1) the difficulty of generating income through subsistence farming contributed to this social class to value species that can be used to treat diseases and/or be traded; (2) even if they had little income from agriculture, farmers, who had access to wild resources, preferred to save this income and use these resources to meet basic needs (food and medicine); and (3) farmers also acted as extractors and commissioned the collection of resources for both medical use and for sale, as there was a strong local credibility for the medicinal effectiveness of this species, just as there was for $H$. drasticus (Baldauf \& Santos 2013). It is known that the greatest involvement in agriculture can lead to the loss of local knowledge, as a result of environmental change and the loss of biodiversity (Martínez-Ballesté et al. 2006). On the contrary, it is also known that people who develop more activities dependent on the natural environment know more species than those that specialize in other activities (see Arias-Toledo et al. 2007; Beltrán-Rodríguez et al. 2014). The fact is that farmers need to use more accessible and viable sources of income and resources, whether native or cultivated, because they do not have professional training for other activities, and in addition, they have a life story directly related to agriculture.

We might expect income to influence the local importance of a higher number of species, as one of the main activities for income generation in the communities is the extraction for commercial purposes, especially in Horizonte. Nonethelessour findings did not corroborate this idea. H. speciosa was the only species that received greater local importance from people with lower incomes in Horizonte. Thus, in the Macaúba, the lower the income, the greater the local importance of $P$. myrsinites (food species), $H$. drasticus (medicinal species) e P. platychepala (animal feeding species). The most financially dependent members of this community observed in this species a good alternative to supply their most basic needs (food and medicine) to the acquisition of products and services.

On the contrary, organoleptic, nutritional and medicinal properties of some wild resources, as well as their versatility, may be the reasons that people with higher incomes people give greater local relevance to certain species (A. intumescens in our case). The characteristic flavor of the fruit and the medicinal efficiency of $A$. intumescens, explained why people with higher incomes valued this species.

Regarding gender, it was observed that men gave greater importance to the species in both communities (two species in each community). This male appreciation may be associated with two factors. The first appeared to be related to the fact that men have greater local knowledge of wildlife areas resources, as suggested in other studies (see Hanazaki et al. 2000; Kristensen \& Balslev 2003; Arias-Toledo et al. 2007; Saynes-Vásquez et al. 2013). It is possible that women gave greater local importance only to certain species or only to one species because they know less about native species than men. For example, in the study by Campos et al. (2015b) conducted in Macaúba, women had limited local knowledge on native food species because they were dedicated to the management and marketing of a single species (A. speciosa); or because they are more involved in caring for the family and have a greater affinity with health and spirituality practices, as Zank \& Hanazaki (2016) observed when conducting a study in this same community. However, this species was not influenced by gender (and by none of the analyzed factors), and this could be explained because men also act, even if to a lesser extent, in the management and marketing of this species. The second explanation was linked to the division of space and work between genders. Such variables that influenced the number of species known or used (see Caniago \& Siebert 1998; Voeks 2007; Camou-Guerrero et al. 2008) may have also interfered with the local importance of the species. As men are responsible for family support, they are the ones who see the more accessible financial alternative to keep the wild resources. Women are strongly involved in the management of the species A. speciosa, as described in the study by Campos et al. (2015b). Perhaps, for this reason they have not given so much importance to the other species when compared to men. Some studies claim that women take care of the home, so they have greater local knowledge of plant resources of anthropogenic areas, such as backyards (Caniago \& Siebert 1998; Voeks \& Leony 2004; Zank \& Hanazaki 2016). However, this might not be the case of this community.

As for education, it was noted that the higher the schooling level the lower the local importance value of $A$. coriaceae and $H$. speciosa in the two communities, except in the case of $S$. rotundifolium in Macaúba, whose relationship is the opposite. In the communities studied, the low income generated by the trade in plant resources, the distance from temporary jobs (cane cutting in the south and southeast regions) and the low value of the benefits provided by the government stimulates the search for an increase in the level of schooling, since this is normaly, a prerequisite for salaried work. This may be the reason for some people move away from forested areas, and consequently, not give so much importance to native resources, although they recognize their importance for the local community. Studies ensured that increased education reduced the chances learn about different native resources (see Benz et al. 2000; Hedge \& Enters 2000; Blancas et al. 2013; Saynes-Vásquez et al. 2013). However, with Sal rotundifolium it is the opposite, 
the lower the level of schooling the higher the value of local importance. Both in Macaúba and Horizonte, people with lower levels of schooling tend to be involved in the management of native forest resources, especially those that generate income and present medicinal use (see Feitosa et al. 2014).

Our finding that the importance of the most salient species (C. coriaceum in Horizonte and A. speciosa and C. coriaceum in Macauba) was not explained by socioeconomic factors is somehow expected. Since most people attributed high values to these species, data on species importance did not vary enough to be explained by socioeconomic factors. Therefore, they can be seen as consensual species to what concerns cultural importance.

\section{Limitation of this study}

The ordering given to plants by informants at the time of data collection did not give a chance for different species to be in the same position. Thus, it was possible that some relations between socioeconomic factors and the value of local importance were not identified.

For the data to remain as close as possible to reality, it was necessary to consider two possibilities: (1) no plant could relate to any socioeconomic factor or (2) all plants could relate to all socioeconomic factors. However, in the way the information was collected, it was impossible to match such prerrogatives. Some significant relations were achieved, but other probable relations may have been underestimated. As each species had its position in the set of relations, others could not have assumed the same place, i.e., the same values of local importance. Hence, this work identified only the stronger relations of factors with the local importance. Therefore, we suggest that other studies requiry the informants to give notes to the plants, instead of using the ranking. Therefore, the different plants cited by the same person may be able to obtain the same note.

\section{Conclusions}

It has been recorded that socioeconomic factors exert influence over local knowledge of plants. Most of the species did not have their local importance influenced by socioeconomic factors. Although, for the small number of remaining species, age was the factor that most explained the importance of culturally salient species. Younger people motivated primarily by the commercial potential of native forest resources tend to attach greater importance to species.

Our results showed that socioeconomic factors exert a weak influence on the local importance of culturally salient plants. This indicates that other factors that also interfere in the functioning of the social-ecological system, such as historical, cultural, ecological and psychological factors, can better explain the local importance of this group of species. However, it is important to clarify that some factors, such as income, may have a weak or null impact because their influence can occur indirectly through interaction with other variables, which could not be detected in the tests adopted. We suggest that later studies should perform a multivariate analysis to verify the level of interaction between the variables, and the influence power of isolated and combined variables. It may be possible to verify whether income would not be a factor of indirect significance in the local importance of culturally salient species.

\section{Acknowledgements}

The authors thank the members of the Horizonte and Macaúba communities for the receptivity and effective participation in all stages of this work; the FACEPE and CNPq; the Instituto Chico Mendes de Conservação da Biodiversidade for their support during the development of this research; and the members of the Laboratorio de Ecologia e Evolução de Sistemas Socioecológicos (LEA), especially Dr. André Borba and Dr. Washington Ferreira Junior, for the fruitful discussions on the idea of this work.

\section{References}

Albuquerque UP, Lucena RFP, Lins Neto EMF. 2014a. Selection of research participants. In: Albuquerque UP, Cunha LVFC, Lucena RFP, Alves RRN. (eds.) Methods and techniques in ethnobiology and ethnoecology. New York, Springer. p. 1-13.

Albuquerque UP, Ramos MA, Lucena RFP, Alencar NL. 2014b. Methods and techniques used to collect ethnobiological data. In: Albuquerque UP, Cunha LVFC, Lucena RFP, Alves RRN. (eds.) Methods and techniques in ethnobiology and ethnoecology. New York, Springer. p. 15-37.

Arias-Toledo B, Colantonio SE, Galetto L. 2007. Knowledge and use of food and medicinal plants in two populations from the Chaco, Cordoba province, Argentine. Journal of Ethnobiology 27: 218-232.

Ayres M, Ayres Junior M, Ayres DL, Santos AAS. 2007. BioEstat: aplicações estatísticas nas áreas das ciências biomédicas. Belém, ONG Mamiraua.

Baldauf C, Santos FAM. 2013. Ethnobotany, traditional knowledge, and diachronic changes in non-timber forest products management: a case study of Himatanthus drasticus (Apocynaceae) in the Brazilian Savanna. Economic Botany 67: 110-120.

Beltrán-Rodríguez L, Ortiz-Sánchez A, Mariano N, Maldonado-Almanza B, Reyes-García V. 2014. Factors affecting ethnobotanical knowledge in a mestizo community of the Sierra de Huautla Biosphere Reserve, Mexico. Journal of Ethnobiology and Ethnomedicine 10:14. doi: 10.1186/1746-4269-10-14

Benz BF, Cevallos J, Santana F, Rosales J, Graf S. 2000. Losing knowledge about plant use in the Sierra de Manantlan Biosphere Reserve, Mexico. Economic Botany 54: 183-191.

Blancas J, Casas A, Pérez-Salicrup D, Caballero J, Vega E. 2013. Ecological and socio-cultural factors influencing plant management in Náhuatl communities of the Tehuacán Valley, Mexico. Journal of Ethnobiology and Ethnomedicine 9: 39. doi: 10.1186/1746-4269-9-39

Borgatti SP. 1996. ANTHROPAC 4.0. Natick, Analytic Technologies.

Brasil. 2012. Política Nacional de Atenção Básica. Série E (Legislação em Saúde). Brasília, Ministério da Saúde.

Camou-Guerrero A, Reyes-García V, Martínez-Ramos M, Casas A. 2008. Knowledge and use value of plant species in a Rarámuri community: a gender perspective for conservation. Human Ecology 36: 259-272.

Campos LZO, Albuquerque UP, Peroni N, Araújo EL. 2015a. Do socioeconomic characteristics explain the knowledge and use of 
native food plants in semiarid environments in Northeastern Brazil? Journal of Arid Environments 115: 53-61.

Campos JLA, Silva TLL, Albuquerque UP, Peroni N, Araújo EL. 2015b. Knowledge, use, and management of the Babassu Palm (Attalea speciosa Mart. ex Spreng) in the Araripe Region (Northeastern Brazil). Economic Botany 69: 240-250.

Caniago I, Siebert S. 1998. Medicinal plant ecology, knowledge and conservation in Kalimantan, Indonesia. Economic Botany 52: 229-250.

Case RJ, Pauli GF, Soejarto D. 2005. Factors in maintaining indigenous knowledge among ethnic communities of Manus Island. Economic Botany 59: 356-365.

Cavalcanti MCBT, Campos LZO, Sousa RS, Albuquerque UP. 2015a. Pequi (Caryocar coriaceum Wittm., Caryocaraceae) oil production: A strong economically influenced tradition in the Araripe region, northeastern Brazil. Ethnobotany Research and Applications 14: 437-452.

Cavalcanti MCBT, Ramos MA, Araújo EL, Albuquerque UP. 2015b. Implications from the use of non-timber forest products on the consumption of wood as a fuel source in human-dominated semiarid landscapes. Environmental Management 56: 389-401.

Cristancho S, Vining J. 2004. Culturally defined keystone species. Human Ecology Review 11: 153-164.

Feitosa IS, Albuquerque UP, Monteiro JM. 2014. Knowledge and extractivism of Stryphnodendron rotundifolium Mart. in a local community of the brazilian savanna, Northeastern Brazil. Journal of Ethnobiology and Ethnomedicine 10:64. doi: 10.1186/1746-4269-10-64

Garibaldi A, Turner N. 2004. Cultural keystone species: implications for ecological conservation and restoration. Ecology and Society 9: 3. doi: 10.5751/ES-00669-090301

Hanazaki N, Tamashiro JY, Leitao-Filho H, Begossi A. 2000. Diversity of plant uses in two Caiçara communities from the Atlantic Forest coast, Brazil. Biodiversity and Conservation 9: 597-615.

Hedge R, Enters T. 2000. Forest products and household economy: a case study from Mudumalai Wildlife Sanctuary, Southern India. Environmental Conservation 27: 250-259.

Holmes C. 2003. Assessing the perceived utility of wood resources in a protected area of western Tanzania. Biological Conservation 111: 179-189.

IBAMA - Instituto Brasileiro do Meio Ambiente e dos Recursos Naturais Renováveis. 2004. Plano de Manejo da Floresta Nacional do Araripe. Brasília, IBAMA. p. 323.

Kristensen M, Balslev H. 2003. Perceptions, use and availability of woody plants among the Gourounsi in Burkina Faso. Biodiversity and Conservation 12: 1715-1739.

Ladio AH, Lozada M. 2004. Patterns of use and knowledge of wild edible plants in distinct ecological environments: a case study of a Mapuche community from Nothwestern Patagonia. Biodiversity and Conservation 13: 1153-1173.

Martínez-Ballesté A, Martorell C, Caballero J. 2006. Cultural or ecological sustainability? The effect of cultural change on Sabal palm management among the Lowland Maya of Mexico. Ecology and Society 11: 27. doi: 10.5751/ES-01803-110227

Medeiros PM, Silva TC, Almeida ALS, Albuquerque UP. 2012. Socioeconomic predictors of domestic wood use in an Atlantic forest area (northeast Brazil): a tool for directing conservation efforts.
International Journal of Sustainable Development \& World Ecology 19: 189-195.

Ostrom E. 2007. A diagnostic approach for going beyond panaceas. Proceedings of the National Academy of Sciences of the United States of America 104: 15181-15187.

Ostrom E. 2009. A general framework for analyzing sustainability of social-cological systems. Science 325: 419-422.

Pennisi E. 2003. Tracing life's circuitry. Science 302:1646-1649.

Platten SJ, Henfrey T. 2009. The cultural keystone concept: insights from ecological anthropology. Human Ecology 37: 491-500.

R Development Core Team. 2013. R: A language and environment for statistical computing. Vienna, R Foundation for Statistical Computing. http://www.R-project.org/

Ramos MA, Medeiros PM, Almeida ALS, Felicinano ALP, Albuquerque UP. 2008. Use and knowledge of fuelwood in an area of Caatinga vegetation in NE Brazil. Biomass and Bioenergy 32: 510-517.

Reyes-Garcia V, Vadez V, Byron E, et al. 2005. Market economy and the loss of ethnobotanical knowledge: Estimates from Tsimane' Amerindians, Bolivia. Current Anthropology 46: 651-656.

Reyes-Garcia V, Vadez V, Tanner S, Huanca T, Leonard WR, McDade T. 2007. Ethnobotanical skills and clearance of tropical rain forest for agriculture: A case study in the lowlands of Bolivia. Ambio 36: 406-408.

Santos LL, Vieira FJ, Nascimento LGS, Silva ACO, Souza GM. 2014. Techniques for collecting and processing plant material and their application in ethnobotany research. In: In: Albuquerque UP, Cunha LVFC, Lucena RFP, Alves RRN. (eds.) Methods and techniques in ethnobiology and ethnoecology. New York, Springer. p. 161-173.

Saynes-Vásquez A, Caballero J, Meave JA, Chiang F. 2013. Cultural change and loss of ethnoecological knowledge among the Isthmus Zapotecs of Mexico. Journal of Ethnobiology and Ethnomedicine 9: 40. doi: 10.1186/1746-4269-9-40

Silva RRV, Gomes LJ, Albuquerque UP. 2017. What are the socioeconomic implications of the value chain of biodiversity products? A case study in Northeastern Brazil. Environmental Monitoring and Assessment 189: 64. doi: 10.1007/s10661-017-5772-2

Silva TC, Campos LZO, Balée W, Medeiros MFT, Peroni N, Albuquerque UP. 2019. Human impact on the abundance of useful species in a protected area of the Brazilian Cerrado. Landscape Research 44: 75-87.

Souto T, Ticktin T. 2012. Understanding interrelationships among predictors of local ecological knowledge. Economic Botany 66: 149-164.

Vandebroek I, Balick M J. 2012. Globalization and loss of plant knowledge: challenging the paradigm. PLOS ONE 7: e0037643. doi: 10.1371/ journal.pone. 0037643

Varughese G, Ostrom E. 2001. The contested role of heterogeneity in collective action: some evidence from community forestry in Nepal. World Development 29: 747-765.

Voeks RA. 2007. Are women reservoirs of traditional plant knowledge? Gender, ethnobotany and globalization in northeastern Brazil. Singapore Journal of Tropical Geography 28: 7-20.

Voeks RA, Leony A. 2004. Forgetting the forest: Assessing medicinal plant erosion in eastern Brazil. Economic Botany 58: S294-S306.

Zank S, Hanazaki N. 2016. Healing faith: knowledge, learning and social relationships of healers from Araripe plateau, Brazil. Ethnobiology and Conservation 5: 1-15. 